\title{
Sultan Mehmed Reşad Döneminde İstanbul'daki Bulgar Cemaati: Nüfus, Yerleşim ve Ekonomi
}

\section{The Bulgarian Community in Istanbul in The Time of Sultan Mehmed Reşad: Settlement, Population and Economy}

\author{
Neriman Ersoy Hacısalihoğlu* (i)
}

*Doç. Dr., İstanbul Üniversitesi, Edebiyat Fakültesi, Tarih Bölümü, İstanbul, Türkiye

\section{ORCID: N.E.H. 0000-0002-1559-9189}

Sorumlu yazar/Corresponding author: Neriman Ersoy Hacısalihoğlu, İstanbul Üniversitesi, Edebiyat Fakültesi, Tarih Bölümü, İstanbul, Türkiye

E-posta/E-mail: nerersoy@istanbul.edu.tr

Başvuru/Submitted: 31.05 .2020 Revizyon Talebi/Revision Requested: 15.06.2020

Son Revizyon/Last Revision Received: 29.06.2020

Kabul/Accepted: 20.07 .2020

\section{Atıf/Citation:}

Ersoy Hacisalihoglu, Neriman. "Sultan Mehmed Reşad Döneminde Istanbul'daki Bulgar Cemaati: Nüfus, Yerleşim ve Ekonomi." Tarih Dergisi - Turkish Journal of History, 71 (2020): 407-428. https://doi.org/10.26650/TurkJHist.2020.019

\section{öz}

Bulgarların İstanbul'a yerleşmesi yoğun olarak 19. yüzyılın ilk çeyreğinde başlamasına rağmen yüzyılın ortalarına doğru İstanbul'un ekonomikhayatında önemli bir konuma ulaşmışlardır. Cemaatin sayısı ticaret, esnaflık ve abacılık gibi zanaatlar yoluyla gittikçe artmış ve İstanbul'daki Bulgarlar, Bulgar kilise hareketinin de öncüleri olmuşlardır. 1870'te Bulgar Eksarhlığı'nın kurulmasıyla birlikte ayrı bir millet olma hakkı elde eden Bulgarlar diğer cemaatler gibi kendi cemaat teşkilatlarını oluşturmuşlardır. Artık Osmanlı Devleti'nin nüfus ve vergi kayıtlarında Bulgar olarak kaydedilmeye başlamışlardır.

Cemaatin nüfusunun ve ekonomik faaliyetlerinin gelişimi hakkında şimdiye kadar birkaç çalışma yapılmışsa da Osmanlı arşiv kaynakları henüz layıkıyla incelenmemiştir. Bu çalışmada Osmanlı nüfus kayıtları ve diğer belgeler değerlendirilerek İstanbul Bulgar cemaatinin 20. yüzyıl başlarındaki nüfusunun yapısı, yerleşim yerleri, meslekleri ve benzeri özellikleri daha ayrıntılı bir şekilde ortaya konmaya çalışılacaktır. Bu şekilde İstanbul Bulgar Cemaati ile ilgili hatıratlardaki veriler yerine arşivlerdeki kayıtların verdiği bilgiler ile durum daha net bir şekilde ortaya konmuş olacaktır.

Bunun yanında Bulgar cemaatinin İmparatorluk başkentinin sosyal ve ekonomik hayatındaki rolü ve konumu da değerlendirilmeye çalışılacaktır.

Anahtar sözcükler: İstanbul, Bulgar cemaati, Bulgar Eksarhlığı, Tüccarlar, Meslekler

\section{ABSTRACT}

In the middle of the $19^{\text {th }}$ century the Bulgarian community began to take on an important position in the economic life of Istanbul. The Bulgarian community increased in number through the engagement of more and more Bulgarians as merchants, shopkeepers and textile workers, and the Bulgarians in Istanbul became the protagonists of the Bulgarian Church Movement. In 1870 Sultan Abdulaziz issued the establishment of the Bulgarian Exarchate and the Bulgarians became a new Orthodox millet. They established their millet organizations and institutions and started to be registered as a separate group in the official Ottoman population registers.

Although there are a few studies about the population structure and economic activities of this community, the Ottoman archival sources have not yet been utilized properly. This study aims to present the population structure, 
the settlement areas, as well as the professions and cultural organizations of the Bulgarian community in Istanbul at the beginning of the $20^{\text {th }}$ century by utilizing Ottoman population registers and other archival documents. In this way, the estimated figures and information about Bulgarians in Istanbul taken from memoirs, will be corrected with more precise figures taken from archival registers and consequently a more realistic picture will be given.

Moreover, the paper also tries to evaluate the general role of the Bulgarian community in the social and economic life of the capital of the Empire.

Keywords: Istanbul, Bulgarian community, Bulgarian Exarchate, Merchants, Professions

\section{Giriş}

Sultan Mehmed Reşad dönemi (1909-1918) -literatürde daha yaygın bir ifadeyle II. Meşrutiyet Dönemi- İstanbul'daki Bulgar cemaatinin gücünün zirvesine ulaşıp hızla küçülmeye başladığı bir dönem olmuştur. Jön Türk Devrimi ile birlikte başlayan yeni dönemde diğer gayrimüslim cemaatleri gibi Bulgarlar da daha aktif bir rol oynamaya başlamıştır. Fakat "Vilâyât-1 Selâse" (Makedonya)'de yeniden başlayan çatışmalar ve Balkan ittifakını kuran Bulgaristan, Yunanistan, Sırbistan ve Karadağ'ın Osmanlı Devleti'nin Balkan topraklarını işgal edip paylaşması İstanbul'daki Bulgar cemaatini olumsuz bir şekilde etkilemiştir. Balkan topraklarının kaybı ve yüz binlerce Müslümanın sığınmacı durumuna düşmesi üzerine Osmanlı hükümetinin gayrimüslim cemaatlere yönelik politikası sertleşecektir. Nitekim Bulgar Eksarhlı̆̆ı'nın merkezi Balkan Savaşlarından sonra İstanbul'dan Sofya'ya taşınacaktır. Aynı süreçte İstanbul'dan Bulgaristan'a yönelik göçler de artacaktır.

İstanbul Bulgarları konusu bilimsel çalışmalarda Rumlar ve Ermeniler kadar yer bulamamıştır. Çünkü sayıları ve oynadıkları rol bakımından daha küçük bir topluluğu oluşturmuş̧lardır. Mevcut çalışmalar arasında en eski ve önemlisi bizzat Bulgar Eksarhlığı'nda çalışan Naço Naçov'un 1925 'te yayınladığı kapsamlı makaledir'. İstanbul Bulgarları ve eğitim hayatları hakkında en son yapılan çalışma ise Orlin Sıbev'in 2019'da yayınladığı eserdir². İstanbul'da yaşamış önemli şahsiyetlerin anıları da İstanbul'daki Bulgar cemaati ile ilgili değerli bilgiler içermektedir ${ }^{3}$. Bulgarların İstanbul ile ilgili anılarından birkaçı kısmen Türkçeye de çevrilmiştir ${ }^{4}$. Bunun dışında İstanbul'da yaşayan Bulgarlar arasından cemaatin tarihi hakkında yakın dönemde yazılmış eserler de bulunmaktadır5.

1 Naço Naçov, "Tsarigrad kato Kulturen Tsentır na B1lgarite do 1877”, Sbornik na BAN, Klon Istoriko-Filosofski i Filosofsko-Obştestven, (19/25), 1925, s. 1-206.

2 Orlin Sibev, Prosveteni na Iztok s Lıçite na Zapada: Bılgarskata Uçeniçeska Koloniya v Tsarigrad (XIX-XX Vek), Izd. “Avangard Prima”, Sofya 2019.

3 Örneğin Simeon Radev, Ranni Spomeni, İzd. Bılgarski Pisatel, Sofya 1969.

4 Efrem Karanov, Mihail Macarov ve Nikola Naçov'un anılarının çevirisi: Hüseyin Mevsim, Bulgar Gözüyle Istanbul: Karanov, Macarov, Naçov, TTK Yay., Ankara 2011.

5 Georgi P. Kostandov, Ístanbullu Bulgarlar ve Eski İstanbul: Geçmişten Günümüze Osmanlı Bakiyesi Bulgarlar Üzerine Bir Araştırma, Kreatif, İstanbul 2011. İç kapakta ayrıca üçüncü alt başlık olarak "Bulgar Cemaatine Mensup Bir Eğitimciden Hatıralar, İzlenimler ve Kişisel Değerlendirmeler” ifadesi yer almaktadır. 
Bu makalede İstanbul'daki Bulgar cemaatinin Sultan Mehmed Reşad dönemi (II. Meşrutiyet dönemi) İstanbul'daki nüfus yapısı, çoğunluğunun Makedonya bölgesinden olduğunu bildiğimiz Bulgarların geldikleri yerler, İstanbul'da ikamet ettikleri semtler ve mahalleler özellikle 1917 tarihli bir nüfus defteri yardımıyla incelenecektir. Bu defter Balkan Savaşları sonrası durumu görmek açısından değerlidir. Ayrıca Bulgarların meslekleri, kültür ve eğitim hayatları da ele alınmaktadır. Çalışmamızda mevcut literatür de değerlendirilerek Cumhurbaşkanlığı Osmanlı Arşivi ve Bulgaristan Merkezi Devlet Arşivi’nden temin ettiğimiz belgeler kullanılmıştır.

\section{İstanbul'da Bulgar Cemaatinin Oluşması ve 1908'e Kadar Gelişimi}

Bulgarların ilk kez İstanbul'a yerleşmesiyle ilgili çeşitli görüşler vardır. Yeni yayınlanan bir çalışmasında Ayşe Kayapınar, Fatih Sultan Mehmet'in 1453'te İstanbul'u fethettikten sonra şehirden kaçanları tekrar geri iskân etmek üzere emir verdiğini ve bunun üzerine birçok Bulgar'ın günümüz Bulgaristan coğrafyasından İstanbul'a gelip yerleştiğini belirtmektedir'6. Dolayısıyla Bulgarların erken tarihlerden beri İstanbul'da yaşadıklarını, ama sayılarının tespitinin mümkün olmadığını söyleyebiliriz.

1826 yılında Yeniçeri Ocağı'nın kaldırılmasıyla beraber askeri alanda reformlar yapılmaya başlandı. Yeni kurulan Asakir-i Mansure-i Muhammediye ordusunun askeri kıyafetlerinin Avrupa tarzında olmasına karar verildi. Ordunun üniformalarının dikimi için dikim atölyeleri ve tekstil fabrikaları kurulmaya başlandı (İstanbul'da 1827'de İplikhane-i Amire ve Dikimhane-i Amire, 1833 'te Feshane-i Amire). Başkentin yün ve kumaş ihtiyacının ana tedarikçisi Balkan coğrafyasıydı. Bu nedenle bu atölye ve fabrikaların kurulduğu bölgelerden biri de Balkan Dağlarının güney etekleri oldu. Nitekim 1835/1836 yılında Balkan Dağının eteğindeki İslimye'de bir tekstil fabrikası kuruldu. Bu fabrika Doğu Balkanların en önemli tekstil üretim merkezi haline geldi. Fabrikanın sorumlu ustası Dobri Jelyazkov bir Bulgar tekstilciydi ve fabrikada ağırlıklı olarak Bulgar abacılar çalışıyordu ${ }^{7}$. Ardından Meriç nehrine yakınlığı nedeniyle ulaşım bakımından avantajlı olan Filibe'ye bağlı Değirmendere'de 18471848'de yeni bir tekstil fabrikası daha kuruldu. Bu fabrikanın kurucusu da Gümüşgerdan isimli, tanınmış bir Bulgar tüccar ailesiydi ${ }^{8}$. Bu fabrikaların işletilmesinde olduğu gibi

6 Ayșe Kayapınar, "XV. ve XVI. Yüzyılda Bulgaristan Coğrafyasından İstanbul'a Yapılan Sürgünler ve İskân". Osmanlı İstanbulu V: V. Uluslararası Osmanlı İstanbulu Sempozyumu Bildirileri, 19-21 Mayls 2017, İstanbul 29 Mayıs Üniversitesi Yay., ed. Feridun M. Emecen, Ali Aky1ldız, Emrah Safa Gürkan, İstanbul 2018, s. 268-269.

7 Mehmet Hacisalihoğlu, "The Rise of Sliven (İslimye) from a Balkan Village to a Province Center in the Ottoman Empire", Turkey and Bulgaria. A Contribution to Balkan Heritage, International Balkan Annual Conference IBAC Book Series 5, ed. Özgür Kolçak, İstanbul Üniversitesi Yay., İstanbul 2017, s. 75-100; ayn. yzr., Doğu Rumeli'de Kayıp Köyler: İslimye Sancağı'nda 1878'den Günümüze Gö̧ler, İsim Değişsiklikleri ve Harabeler, Bağlam Yay., İstanbul 2008, s. 74-77.

8 Neriman Ersoy Hacısalihoğlu, "Textile Trade in Bulgaria in the Mid-Nineteenth Century and the Gümüşgerdan Family", Living in the Ottoman Ecumenical Community: Essays in Honour of Suraiya Faroqhi, ed. Vera Costantini, Markus Köller, Brill, Leiden 2008, s. 181-199; ayn.yzr., XIX. Yüzyılda Filibe Şehri (1839-1876), İstanbul Üniversitesi Sosyal Bilimler Enstitüsü, Yayınlanmamış Doktora Tezi, İstanbul 2004, s. 244-246. 
bölgedeki genel tekstil (aba) üretiminde de Bulgarların öncü bir rolü vardı. Osmanlı Devleti tarafından verilen siparişler, İslimye ve Filibe'de üretilen aba kumaşları, Bulgar tüccarları vasıtasıyla İstanbul'a getirilmiştir. Yalnızca üretimde değil İstanbul'daki Dikimevinde de yoğun olarak Bulgar terziler çalıştırılmıştır. Bu şekilde Bulgarların İstanbul'a göçü ve yerleşmesi hızlanmıştır. İstanbul'a gelen Bulgarların bir kısmı mevsimlik işçi statüsünde iken bir kısmı da kalıcı olarak başkente yerleşmiştir. Terziliğin yanında celeplik, bahçıvanlık gibi başka mesleklerle de İstanbul'a yerleşen Bulgarlar arasında dikkate değer bir tüccar sınıfı oluşmuştur. İstanbul'daki Bulgar cemaatinin ekonomik merkezi ise Balkapanı Han ve civarı olmuştur'. Zamanla İstanbul'da kendi iş yerini açan Bulgarların sayısı artmıştır.

$\mathrm{Bu}$ süreçte sayıları artan ve güçlenen Bulgar cemaati 19. yüzyılın ortalarına doğru Rum Patrikhanesine karşı bir mücadele başlatıp ayrı bir kilise talep etmişlerdir. Bu talebin en önemli gerekçelerinden biri ise Bulgarlar arasında Rumca bilmeyenlerin bulunması ve dolayısıyla kilisede ibadet dilinin ana dillerinde olması arzusudur. Bu şekilde Bulgar kilise hareketinin milli bir hareket olduğu ve bu hareketi Bulgar milliyetçi hareketinin takip ettiği görülecektir. 1860 yılına gelindiğinde ise artık Bulgar cemaati kendisinde Rum Patrikhanesine karşı açıkça meydan okuyacak cesareti bulmuştur ve Paskalya ayininde Bulgar papaz İlarion Makariopolski Rum Patriğinin otoritesini tanımadığını ilan etmiştir. Ardından başlayan "Eksarhlık kavgası" on yıl boyunca aralıksız devam etmiş ve Rumlara karşı bu mücadelede İstanbul Bulgar cemaati hem Rum Patrikhanesine hem de Osmanlı yönetimine varlığını kabul ettirmeyi başarmıştır. İstanbul Bulgarlarının bu direnci ve gayretleri sayesinde ve Rusya'nın da diplomatik desteğiyle 1870’te Bulgar Eksarhlığı kurulmuştur ${ }^{10}$.

Padişahın fermanı ile ayrı millet olma hakkını kazanan Bulgarlar, Osmanlı kayıtlarında ilk kez ayrı olarak "millet-i Bulgar” şeklinde kaydedilmeye başlanmışlardır. Ancak bu sayede Bulgar cemaatinin nüfus verilerini Rumlardan ayrı olarak görebilmek mümkün olabilmiştir. Rum Patrikhanesi gibi Bulgar Eksarhlığı'nın da merkezi İstanbul olmuştur. Bulgar cemaati daha önce içinde bulunduğu Rum Patrikhanesini kendisine örnek almış, diğer milletler gibi din, eğitim ve ekonomi alanında faaliyetlerini arttırarak İmparatorluğun gayrimüslim cemaatlerinden biri olmayı başarmıştır.

1860’ta başlayan mücadele sürecinde bir kısım Bulgarlar Papa ile iletişime geçerek Patrikhane'den ayrılıp Papa'nın ruhani otoritesi altına girmişlerdir ve bu şekilde 1860/1861'de İstanbul'da bir Katolik Bulgar cemaati oluşmuştur. Katolik Bulgar cemaati de Osmanlı kayıtlarında ayrı bir cemaat olarak kaydedilmiştir ${ }^{11}$.

9 Neriman Ersoy Hacısalihoğlu, “19. Yüzyıl İstanbul’unda Bulgar Tüccarları ve Bulgar Cemaati”, İstanbul: Imparatorluk Başkentinden Megakente, ed. Yavuz Köse, çev. A. Dağlı, Kitap Yay., İstanbul 2011, s. 176-199.

10 Daha fazla bilgi için bkz. M. Hüdai Şentürk, Osmanlı Devleti’nde Bulgar Meselesi (1850-1875), TTK Yay., İstanbul 1992.

11 Elçin Macar, İstanbul'un Yok Olmuş İki Cemaati. Doğu Ritli Katolik Rumlar ve Bulgarlar, İletişim Yay., İstanbul 2002, s. 96-102. 
1877-1878 Osmanlı Rus savaşının akabinde önce Ayastefanos Antlaşmasıyla "Büyük Bulgaristan”, daha sonra ise imzalanan Berlin Antlaşmasıyla beraber Bulgaristan Prensliği ve Doğu Rumeli Vilayeti kurulacaktır. Ancak 1885 yılında Bulgaristan Prensliği, Doğu Rumeli Vilayetini ilhak ederek sınırlarını genişletmiştir ${ }^{12}$. Bu aşamadan sonra Bulgarların ana amacı, Osmanlı Devleti sınırları içinde kalan "Viâyât-1 Selâse" (Makedonya)'yi kendi topraklarına dahil etmek olmuştur. Bulgarların 1890'larda Makedonya örgütlerinin de kurulmasıyla eğitim ve kilise faaliyetleri yanında komitacılık faaliyetlerine yönelmesi üzerine bu topraklarda SırpRum-Bulgar rekabeti kızışmıştır. Her ülke kendi eğitim ve dini kurumlarını yaygınlaştırma çabası içerisine girerek kendi nüfusunun diğer milletlerden fazla olduğunu iddia etmiştir ${ }^{13}$. $\mathrm{Bu}$ şekilde Balkan devletleri arasında "Makedonya sorunu" olarak bilinen mesele ortaya çıkmıştır ${ }^{14}$. Komitelerin çeteler kurarak tedhiş harekatını başlatması ve bölgeyi terörize etmesiyle birlikte sorun dünya gündemine oturmuştur ${ }^{15}$. Bu süreç 1903 yılında gerçekleşen İlinden isyanıyla doruk noktasına ulaştı ${ }^{16}$. Osmanlı Devleti'nin Balkan topraklarında yaşanan silahlı ayaklanmalar ve bu isyanların bastırılması sürecinde gerçekleşen çatışmalar ${ }^{17}$ nedeniyle "Vilâyât-1 Selâse"de yaşayan Bulgarların bir kısmı Bulgaristan Prensliğine kaçmış, bir kısmı ise İstanbul'a göç etmiştir. Nihayet Bulgaristan'ın bağımsızlığının ilan edildiği 1908 yılında İstanbul'da ciddi sayıda Bulgar nüfus bulunmaktaydı.

II. Meşrutiyet'in ilanından sonra başlayan ve bu incelemenin de konusunu oluşturan yeni dönemde İttihad ve Terakki Cemiyeti'nin merkeziyetçi politikaları diğer gayrimüslim cemaatler gibi Bulgar cemaatini de etkiledi. Buna rağmen Balkan Savaşlarına kadar Bulgarlar faaliyetlerini artırarak devam ettirdiler ${ }^{18}$. Balkan Savaşları sonrası Osmanlı Devleti'nin bu cemaate karşı tavrı ve politikası değişecektir. Nitekim 1913'e kadar genişleyen cemaat bu yıldan itibaren hızla küçülecek ve etkisini kaybetmeye başlayacaktır.

\section{Yüzyılın Başlarında İstanbul'daki Bulgarların Nüfusu}

Yukarıda bahsettiğimiz gibi Ortodoks tebaa Rum Patrikhanesine bağlıydı ve Osmanlı belge ve defterlerinde 1870'e kadar "Millet-i Rum" adı altında kaydedilmişlerdi. Bu nedenle

12 Mahir Aydın, Şarki Rumeli Vilayeti, TTK Yay., Ankara 1992.

13 Makedonya'daki Bulgar okulların durumuyla ilgili bkz. Neriman Ersoy Hacısalihoğlu, "Bulgar Eksarhı Yosif'in Yazışmalarında Makedonya'daki Bulgar Okulları", Osmanlıdan Cumhuriyete Sosyo-Kültürel Siyasi Yansımalar, (Prof. Dr. Ali İhsan Gencer Anısına), ed. G. Sarıyıldı,, F. Ürekli, R. Karacakaya, N. E. Hacısalihoğlu, Derin Yay., İstanbul 2015, s. 137-156.

14 Kemal Beydilli, "II. Abdülhamid Devrinde Makedonya Meselesine Dair”, Osmanlı Araştırmaları, sayı IX'dan ayrı basım (1989), s. 77-98.

15 Çete faaliyetleri için bkz. Mahir Aydın, “Arşiv Belgeleriyle Makedonya’da Bulgar Çete Faaliyetleri”, Osmanlı Araştırmaları, sayı IX (1989), s. 209- 234.

16 Fikret Adanır, Makedonya Sorunu, Oluşumu ve 1908'e Kadar Gelişimi, çev. İ. Catay, Tarih Vakfı Yurt Yay., İstanbul 2001, s. 192-213; Yakup Ahbab, “Amerikan ve İngiliz Basınında İlinden İsyanı (1903)”, Karadeniz Araştırmaları Enstitüsü Dergisi, I/1 (2015), s. 119-151.

17 Gül Tokay, Makedonya Sorunu. Jön Türk İhtilalinin Kökenleri (1903-1908), Alfa Yay., İstanbul 1996.

18 Mehmet Hacısalihoğlu, Jön Türkler ve Makedonya Sorunu (1890-1918), çev. İ. Catay, Tarih Vakfı Yurt Yay., İstanbul 2008, s. 171-421. 
1831'de yapılan kapsamlı nüfus kaydında Bulgarları ayrı bir cemaat olarak belirlemek mümkün değildir. Ancak bölge ve şahıs isimlerine bakarak bazı sınırlı tespitleri yapma imkânı olabilir. 1870 yılında Osmanlı Devleti’nin Bulgar Eksarhlığı’nın kurulmasına izin vermesiyle birlikte bu durum değişmiştir.

Şimdiye kadar yapılan çalışmalarda İstanbul'daki Bulgar nüfusuyla ilgili çeşitli

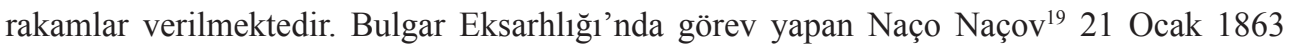
tarihli "Bılgariya" gazetesine dayanarak İstanbul'da toplam 32.550 Bulgar bulunduğunu yazmaktadır. Bunların 8.000'i abacı, 5.000'i tüccar, 4.000'i ekmekçi, 3.500'ü bahçıvan, 2.000'i faytoncu, 2.550'si balıkçı, 600'ü mutafçı (dokumacı), 1.500'ü hizmetkâr ve aşç1, 3.000'i çiftliklerde çalışan 1rgat, 1.500'ü çoban, 400'ü tütüncü ve 500'ü derici (debbağ) idi²0.

Naçov’un verdiği rakamların Osmanlı nüfus kayıtlarının epeyce üzerinde olduğu görülmektedir. Nitekim Kemal Karpat'ın incelediği 1881-1893 arası nüfus sayımı verilerine göre İstanbul'da 3.977 Bulgar erkek ve 400 Bulgar kadın yaşamaktayd ${ }^{21}$. Aynı dönemle ilgili olup Orlin Sabev tarafından 1881-1882 sayımıyla ilgili olduğu tahmin edilen bir Osmanlı nüfus defterinde ise toplam 1.245 Bulgar erkek kayıtlıdır. İleriki yıllarda da Bulgar cemaatinin nüfusuyla ilgili veriler mevcuttur. Örneğin 1894'te 5.758, 1906/1907'de 2.290 Bulgar kayıtlıdır. Rakamlar arasındaki bu keskin farklılığın kayıt defterlerinin kapsadığı semtlerin farklı olmasıyla ilgili olduğu, yani rakamların düşük olduğu kayıtlarda İstanbul Suriçi'nin ve Eyüp semtinin dahil edilmediği anlaşılmaktadır ${ }^{22}$. Osmanlı kayıtlarına göre ise 1902 (H. 1320) yılında 3.819 ve 1905 (H. 1323)’te 3.221 Ortodoks Bulgar erkek nüfus mevcuttu²3.

Cuma-i Bala ve İlinden isyanlarını müteakip birçok Bulgar Makedonya'dan firar edecektir ${ }^{24}$. Bir kısmı Bulgaristan Prensliği topraklarına firar ederken²5, çoğunluğu İstanbul'a

19 1898-1909 y1llar arasında İstanbul'daki Bulgar Eksarhlığı'nda görevde bulunmuştur. İstanbul'daki Bulgar cemaatiyle ilgili birçok kitap yayınlamıştır.

20 Naçov, a.g.m., s. 176-179.

21 Kemal H. Karpat, Ottoman Population, 1830-1914: Demographic and Social Characteristics, The Univ. of Wisconsin Press, Madison 1985, s. 146.

22 Orlin Sabev, "Bulgaristan'da Muhafaza Edilen 1299/1881-82 Tarihli Bir Nüfus Defterine Göre Osmanlı İstanbulu'nun Bahçe ve Dükkanlarında Çalışan Bulgarlar”, Osmanlı Ístanbulu V, ed. F. M. Emecen, A. Akyıldız, E. S. Gürkan, İstanbul 29 Mayıs Üniversitesi Yay., İstanbul 2018, s. 610-611.

23 BOA, YEE, no. 310 (1320), no. 319. (1323)

24 İlinden isyanı Makedonya'nın geneline yayıldı ve 30.000'e yakın isyancı Osmanlı Devleti'nin gayrimüslimlere yönelik baskıcı bir politika takip ettiğini göstermek istedi. Bu şekilde Avrupa devletlerinin bölgeye dikkatlerini çekebileceklerini düşündü; fakat isyan bastırıldı. Bundan sonra Mürzsteg reformları uygulamaya konuldu. Adanır, a.g.e., s. 217-218.

25 İlhan Tekeli de Bulgaristan’a göç eden Bulgarların sayısının 30.000 kişi olarak vermiştir. İlhan Tekeli, "Makedonya İç Devrimci Örgütü ve 1903 İlinden Ayaklanması", Cumhuriyetin Harcı/Köktenci Modernitenin Doğuşu, haz. İlhan Tekeli-Selim İlkin, Bilgi Üniversitesi Yay., 3. Bask1, İstanbul 2010, s. 76; 15 Eylül 1903 tarihli Osmanlı arşiv belgesinde Varna'ya yaklaşık 2.000 kişi geldiği ve onlara yardım etmek amacıyla bir komisyonun oluşturulduğu belirtilmektedir. $\mathrm{Bu}$ komisyon Varna'da yaşayan vatandaşlara Makedonya bölgesinden gelen Bulgarlar için yardım çağrısında bulunmuştur. BOA, HR.SFR (04), 253/34. 
göç etmiştir. Dolayısıyla bu göçle birlikte İstanbul'da yaşayan Bulgarların sayısının arttığını söylemek mümkündür. Fakat kısa süre sonra Avrupa devletleri tarafindan yapılan baskılar sonucu isyancılara yönelik Osmanlı Devleti bir af çıkarmak zorunda bırakılmıştır²6.

Bağımsız Bulgaristan'ın kuruluşunu müteakip Osmanlı tebaası Bulgarların çoğu Bulgaristan tabiiyetine geçmiştir. 1917 tarihli nüfus defterine göre İstanbul'daki Bulgarların çoğunun Bulgaristan vatandaşı olup çalışmak amacıyla İstanbul'a geldikleri anlaşılmaktadır. 1912 Balkan savaşlarının başlaması ile siyasi sebeplerden dolayı Bulgar Eksarhı'yla beraber sadece İstanbul'dan değil Trakya bölgesinden de birçok Bulgar, Bulgaristan veya Makedonya bölgesine geri dönmüştür ${ }^{27}$.

Balkan savaşları sürecinde Bulgaristan'ın ve diğer Balkan devletlerinin Müslümanlara karşı uyguladığı katliam ve tehcir politikası, İstanbul Bulgarları için olumsuz bir sürecin başlamasına da neden olmuştur. Osmanlı Devleti ile Bulgaristan arasında 1913 Mart'ta ateşkes imzalanmasının ardından yaklaşık iki aylık bir süre içinde İstanbul ve Çatalca'da yaşayan Bulgarların önemli bir kısmı göçe zorlanmış veya savaşın yarattığı olumsuz atmosfer nedeniyle İstanbul'dan göç etmiştir ${ }^{28}$.

26 Ağustos 1915 tarihli bir raporda Balkan savaşları sonrası İstanbul'daki nüfusla ilgili bilgiler Metropolit tarafından aktarılmaktadır. Buna göre Balkan savaşları sonrası Osmanlı Devleti ve Bulgaristan arasında imzalanan İstanbul Antlaşmasının akabinde İstanbul ve Çatalca'da yaşayan Bulgarların göç etmeye başladığı belirtilmiştir. Burada yaşayan Bulgar nüfusunun 2 ay içinde mal varlıklarını bırakarak gönderildikleri ve her ailenin sadece bir araba yükü ev eşyası almasına müsaade edildiği yazılmıştır. Bu esnada Bulgarlara Hükümet tarafından takip ve baskı yapıldığı, Eksarhlığın yetkililerle görüşmelerine rağmen sonucun değişmediği belirtilmiştir. Hükümette bulunan ve aynı zamanda Dahiliye Nazırlığ 1 görevini yürüten Talat Bey ile görüşülerek Bulgarların mal varlıkları sorununun çözümü için bir komisyonun kurulması istenmiştir; fakat bu da sonuçsuz kalmıştır. Savaştan sonra Anadolu'da yaşayan Ortodoks Bulgarlar da göç etmeye başlayınca Bulgar Parlamentosu bir görevli göndererek göç edenlere yardım etmiştir. Bu tarihlerde Bulgar nüfusun sadece İstanbul, Edirne ve Kırklareli’nde kaldığg belirtilmiştir ${ }^{29}$.

Mehmed Reşad döneminde İstanbul'daki Bulgarların nüfusuyla ilgili bilgileri ise Bulgar Eksahlığı'nda görevli Eksarh vekilinin yukarıda bahsetmiş olduğumuz raporundan

26 BOA, A.MTZ (04), 116/50 lef 6. Belgeye göre 40 gün içinde (30 Mart 1320) firar eden kişiler bulundukları en yakın şehre gidip Osmanlı idaresini kabul ettiklerini ve bir daha isyancı olmayacaklarını bildirdikleri takdirde doğdukları evlerine geri dönebileceklerdir. Bu süre zarfinda bunu yapmayanlar takip edilecekler ve yakalandıklarında yürürlükteki kanunlar uygulanacaktır.

27 Sibev, a.g.e., s. 55-56.

28 TsDA, F. 246 K, op. 2, a.e. 15, 1. 1-3.

29 TsDA, F. 246 K, op. 2, a.e. 15, 1. 3. Bu belgede Edirne'de yaklaşık 300, Kırklareli'de 350 aile yaşadığı yazılmıştır. 
öğreniyoruz. Buna göre Balkan savaşından sonra 1915 yılında İstanbul'da 700 hane civarında Bulgar kalmıştır. Nüfusla ilgili diğer bir bilgiyi yine kendilerinin tutmuş oldukları defterden öğreniyoruz. 19 Haziran 1917 tarihli defter, rahip İkonom St. Kostov tarafindan tutulmuştur. Kendi tuttuğu kayıtta 488. sırada yer alan rahip Kostov Debreli olup Fener'de oturmakta, evli ve beş kızı olduğu anlaşılmaktadır. Bununla birlikte Bulgaristan vatandaşı olduğu belirtilmektedir. Bu nüfus defteri daha önce Vanya Stoyanova tarafından incelenmiş ve Bulgarların İstanbul'daki nüfusunun gelişimi bağlamında değerlendirilmiştir ${ }^{30}$.

$\mathrm{Bu}$ defterde Ortodoks Bulgar hane reislerinin isimleri, geldikleri şehir, İstanbul'da ikamet ettikleri semt, tabiiyetleri, yaşları ve meslekleri ayrı ayrı kaydedilmiştir. Defterden İstanbul'daki Bulgarların bir kısmının Bulgaristan ve bir kısmının da Osmanlı tabiiyetine mensup oldukları anlaşılmaktadır. Evli veya bekar oldukları belirtilmiştir. Ayrıca kadınların isimleri yazılmamışsa da her hanede kaç kadının bulunduğu, kadın ve erkeklerin her hane için sayıları toplam olarak defterde kaydedilmiştir. Defterde nüfus verilerinin sonunda 1.094 erkek ve 640 kadın olmak üzere 1.737 Bulgar nüfusun toplam sayısı olarak verilmiştir. Defteri yakından incelediğimizde defterde hane/kişi sırası 497'ye kadar geliyor ise de toplam 24 numara tekrar etmekte ve 3 numara ise atlanmış olup listede yer almamaktadır. Bunların toplamına göre listede toplam 518 sıralanmış isim (hane reisi) yer almaktadır ${ }^{31}$.

Bunlar genelde Ortaköy, Beşiktaş, Fındıklı, Fener, Şişli, Pangaltı, Tatavla, Taksim, Kasımpaşa, Ayvansaray, Eyüp Sultan, Çukur Cuma, Galata, Pera, Kumkapı, Yedikule, Makriköy, Topkapı, Langa, Davutpaşa, Yusufpaşa, Küçük Langa, Aksaray, Şehzadebaşı, Balıkpazarı, Edirnekapı, Üsküdar, Kuzguncuk, Kadıköy, Beylerbeyi, Çengelköy, Bebek, Yeniköy, Büyükada, Heybeliada gibi yerlerde ikamet etmiştir ${ }^{32}$.

Bu nüfus kaydının detaylarına bakıldığında şöyle bir tablo ortaya çıkmaktadır: 1917 tarihli nüfus kaydına göre İstanbul'da hane reisi olarak kayıtlı -sayarak tespit ettiğimiz507 Bulgar hane reisinden (veya bekar Bulgar erkekten) 328'i (\%64,6) Bulgaristan vatandaşı, 179'u ise (\%35,3) Osmanlı vatandaşıdır. Buna göre bu tarihte İstanbul' da ikamet eden Bulgarların yalnızca üçte birinin Osmanlı vatandaşı olduğu, büyük çoğunluğun ise Bulgaristan'ın tabiiyetine sahip olduğu görülmektedir. Bunun da anlamı bunların çoğunluğunun asıl ikametlerinin Bulgaristan olduğu ve geçici olarak, çalışma amacıyla İstanbul'da bulunduklarıdır.

30 Vanya Stoyanova, "Kım Viprosa na Çislenostta na Tsarigradskata Bılgarska Koloniya (1913-1945)", Sine ira et studio, Izsledvaniya v Pamet na Prof. Zina Markova, ed. Konstantin Kosev, Aİ. "Prof. Marin Drinov", Sofya 2010, s. 415-424. Ayrıca bkz. Orlin Sibev, Prosveteni na Iztok s Lıçite na Zapada: Bılgarskata Uçeniçeska Koloniya v Tsarigrad (XIX-XX Vek), Izd. "Avangard Prima", Sofya 2019, s. 55.

31 Tekrar eden numaralar: 134, 135, 142-148, 454; numarasız satırlar: 367 ile 368 arasında bir, 445 ile 446 arasında bir, 482 ile 483 arasında 10 satır, 483 ile 484 arasında iki satır; eksik numaralar: 161, 388, 494.

32 TsDA, F. 246 K, op. 5, a.e. 275. 
Nüfus kaydında bu kişilerin geldikleri yerler şehir, köy ve kaza isimleriyle kaydedilmiştir. Söz konusu nüfus kayıtlarından anlaşıldığı kadarıyla İstanbul'daki Bulgarların çoğu Makedonya topraklarından göç etmişlerdi. İstanbul'a gelen 518 Bulgar aile reisinin geldikleri yerlere göre sayıları şöyledir ${ }^{33}$ :

\begin{tabular}{|l|l|}
\hline \multicolumn{1}{|c|}{$\begin{array}{c}\text { Tablo 1 } \\
\text { 1917'de İstanbul'da Yaşayan Bulgarların Doğum Yerlerine Göre Sayısı }\end{array}$} \\
\hline Kostur (Kesriye/Kastoria/1912 Yunanistan) & 150 \\
\hline Resen (Resne, 1912 Sırbistan) & 127 \\
\hline Lerin (Florina/Yunanistan) ve çevresinden & 82 \\
\hline Kaylari (Kayalar) ve Çevresinden (1912 Yunanistan/1927 Ptolemaida & 40 \\
\hline Debır (Debre, 1912 Sirbistan) & 16 \\
\hline Ohrid (Ohri, 1912 Sırbistan) & 12 \\
\hline Bitola (Manastrr, 1912 Sırbistan) & 12 \\
\hline Tetovo (Kalkandelen, 1912 Sırbistan) & 6 \\
\hline Gostivar (1912 Sirbistan) & 6 \\
\hline Serez (1912 Yunanistan) & 5 \\
\hline Vırben (1912 Sırbistan) & 2 \\
\hline Veles (Köprülü/1912 Sirbistan) & 1 \\
\hline Prilep (Pirlepe, 1912 Sirbistan) & 1 \\
\hline Kukuş (1912 Yunanistan) & 1 \\
\hline Fere (Ferecik, 1912 Blg., 1920 Yunanistan) & 1 \\
\hline Voden (Vodina, 1912 Yunanistan) & 1 \\
\hline Gyusen (1912, Yunanistan) & 1 \\
\hline Şalin? (İpero) (1912 Yunanistan) & 1 \\
\hline
\end{tabular}

Toplamda 465 hane reisi, yani İstanbul'daki Bulgarların \%89,7'si Makedonya'nın farklı kazalarından gelmektedir. Makedonya bölgesinde Manastır vilayetine bağlı ve Manastır'ın batısında kalan kazalardan, yani Batı Makedonya'dan gelenler (440 kişi) büyük çoğunluğu oluşturmaktadır. Manastır'ın batısındaki kazalardan gelenlerin toplam Bulgar nüfusuna oranı \%85'tir. Neden bu bölge Bulgarlarının İstanbul'a daha çok göç edip yerleştiği sorusu ayrıca önemlidir. Kesriye (Kostur)'den gelenlerin çoğunlukla sütçü (mlekar), Resne ve Kayalar'dan gelenlerin ise daha ziyade bahçıvan (gradinar) ve çiçekçi oldukları görülmektedir.

33 TSDA, F 246 K, op. 5, a.e.275, 1. 2-22. 


\begin{tabular}{|l|l|}
\hline \multicolumn{2}{|c|}{ Tablo 2 } \\
\hline \multicolumn{2}{|c|}{ 1917'de İstanbul'da Yaşayan Bulgaristan'da Doğmuş Bulgarların Sayısi } \\
& \multicolumn{2}{l}{} \\
\hline Bulgaristan & 3 \\
\hline Koprivştitsa (Bulgaristan) & 17 \\
\hline Kalofer (Bulgaristan) & 8 \\
\hline Plovdiv (Filibe, 1885 Bulgaristan) & 3 \\
\hline Sliven (İslimye) (Bulgaristan) & 2 \\
\hline Debrıştitsa (Bulgaristan) & 2 \\
\hline Karlovo (Bulgaristan) & 2 \\
\hline Varna (Bulgaristan) & 2 \\
\hline Gabrovo (Bulgaristan) & 1 \\
\hline Panagyurişte (Bulgaristan) & 1 \\
\hline Jeravna (Bulgaristan) & 1 \\
\hline Kadirşmıkli (Kadirşik) (Bulgaristan 1934 Streltsi) & 1 \\
\hline
\end{tabular}

Toplamda Bulgaristan'dan 43 kişi (hane reisi) gelmiştir. Bu da İstanbul'daki toplam Bulgarların \% 8,3'üne tekabül etmektedir. Bulgaristan'dan İstanbul'a gelenlerin ise çoğunluğu genellikle Koprivştitsa (Avretalan), Kalofer, Plovdiv (Filibe) gibi daha ziyade tüccarlarıyla tanınan merkezlerdendir. Bunların ana mesleğinin abacılık olduğu görülmektedir.

\begin{tabular}{|l|l|}
\hline \multicolumn{2}{|c|}{ Tablo 3} \\
1917'de İstanbul'da Yaşayan İstanbul ve Edirne Çevresinde Doğmuş Bulgarların Sayısi ${ }^{35}$ \\
\hline İstanbul & 7 \\
\hline Çengelköy & 1 \\
\hline Bunarhisar (Pnnarhisar) & 1 \\
\hline Odrin (Edirne) & 1 \\
\hline
\end{tabular}

İstanbul ve Osmanlı elinde kalan Trakya topraklarından ise toplamda 10 kişi gelmektedir. İstanbul doğumlu veya İstanbullu olarak kaydedilen toplam 8 kişi bulunmaktadır. Bu da 1917'de İstanbul'da yaşayan Bulgarların yalnızca \%1,5'inin aslen İstanbullu olduğunu göstermektedir. Fakat İstanbullu olarak kaydedilen bu kişilerden biri hariç tamamının Bulgaristan vatandaşı olduğu belirtilmektedir.

İstanbul'da ikamet ettikleri yerlere baktığımızda büyük çoğunluğunun Avrupa yakasında Kasımpaşa, Şişli, Eyüp Sultan, Defterdar, Ortaköy, Beşiktaş, Galata, Hendek Alayı, 
Çukurcuma, Aksaray (Etmeydanı), Kumkapı, Yedikule, Bakırköy (Makriköy), Langa, Fener ve Eminönü bölgesindeki hanlar; Anadolu yakasında ise Kadıköy olduğu görülmektedir. İkamet yerlerinin detaylı listesi -sayarak tespit edebildiğimiz rakamlarla (hane reisi sıralamasına göre)- şöyledir ${ }^{36}$ :

\begin{tabular}{|c|c|c|c|}
\hline \multicolumn{4}{|c|}{$\begin{array}{c}\text { Tablo } 4 \\
\text { 1917'de Bulgarların İstanbul'da Yaşadıkları Yerler }\end{array}$} \\
\hline Yerleşim Yeri & Hane Sayısı & Yerleşim Yeri & Hane Sayısı \\
\hline Ortaköy & 16 & Horhor cadde & 1 \\
\hline Beşiktaş & 11 & Kule Bostan & 1 \\
\hline Findıklı & 8 & Arkapı (Ahırkapı?) & 1 \\
\hline Şişli & 32 & Kairikale (?) & 1 \\
\hline Tatavla & 1 & Kumkapu & 19 \\
\hline Pangalt1 & 5 & Edikule (Yedikule) & 22 \\
\hline Taksim & 2 & Makriköy [Bakırköy] & 12 \\
\hline Kalancikumu (?) & 5 & Tatlikoyu (Tatl1-köy?) & 1 \\
\hline Aynalıçeşme & 1 & Silivrikap1 & 3 \\
\hline Kasımpaşa & 88 & Topkap1 & 1 \\
\hline Küçük Piyale & 1 & Stamiatya [Samatya] & 4 \\
\hline Lonca & 3 & Dautpaşa [Davutpaşa] & 5 \\
\hline Ayvasar [Ayvansaray] & 2 & Yusufpaşa & 1 \\
\hline Tevtedar [Defterdar] & 5 & Küçük Vlanga [Küçük Langa] & 10 \\
\hline Eniçeşme (Yeniçeşme) & 1 & Vlanga [Langa] & 13 \\
\hline Eyüp-skele (Eyüp iskelesi) & 1 & Aksaray & 1 \\
\hline Eyüb Sultan & 21 & Edrene kapu (Edirnekapı) & 3 \\
\hline Balata (Balat) & 4 & Oca paşe (Hocapaşa) & 1 \\
\hline Asıköy (Yassıköy) & 11 & Tauk pazarı (Tavukpazarı) & 1 \\
\hline Abduramen-mahle (Abdurrahman Mah.) & 1 & Sirkeci & 4 \\
\hline Barya & 2 & Alaca-amam (Alacahamam) & 1 \\
\hline Tırlabaşı (Tarlabaşı) & 1 & Tütün-gümrük & 1 \\
\hline Arab camesi & 1 & Uzunçarş1 & 1 \\
\hline Perşembe Pazarı & 1 & Ayazmakapu & 1 \\
\hline Ah1-kaagam (?) & 2 & Bılık Pazari (Balık Pazarı) & 7 \\
\hline Galata & 26 & Enikapı (Yenikapı) & 1 \\
\hline Mumhane caddesi & 1 & Şesedebaşi (Şehzadebaşı) & 3 \\
\hline Pera & 1 & Fener & 11 \\
\hline Endek-galaya [Hendek Alayı] & 13 & B1lıkliya (Balıklı) & 1 \\
\hline
\end{tabular}

36 TSDA, F 246 K, op. 5, a.e.275, 1. 2-22. 


\begin{tabular}{|l|l|l|l|}
\hline Tophane & 2 & Uskudarı (Üsküdar) & 5 \\
\hline Eniçarşi (Yeniçarş1) & 3 & Kadiköy (Kadıköy) & 15 \\
\hline Voyvoda cadde $^{37}$ & 1 & Kuskuncuk (Kuzguncuk) & 3 \\
\hline Sreştu Bankata (?) 38 & 2 & Feneryolu (Asya sahili) & 2 \\
\hline Pera-bayır & 1 & Gyost-tepe (Göztepe) & 1 \\
\hline Çukur-cuma & 5 & Renköy (Erenköy) & 2 \\
\hline Venedik sokak & 1 & Belerbey (Beylerbey) & 1 \\
\hline Tepe başe (Tepebaş1) & 1 & Çengelköy & 2 \\
\hline Kule kap1 & 1 & Bebek & 1 \\
\hline Okçu Musa Caddesi & 1 & Eniköy (Yeniköy) & 1 \\
\hline Emek-Emes-Mah. (Emekyemez Mah.) & 8 & Ostr. Prinkipa [Büyükada] & 2 \\
\hline Papasköprü (Kasımpaşa) & 2 & Ostr. Halki [Heybeliada] & 2 \\
\hline Çarşamba & 4 & Sv. Stefan [Ayastefanos/Yeşilköy] & 7 \\
\hline Saragüzel (Stambol) & 3 & Stambol Kürçi Han & 12 \\
\hline Ed-Megdan [Aksaray] & 3 & Vezirhan & 3 \\
\hline Eni-Balçe-Ed-megdan & 14 & Ejiler(?) [Etiler?] & 2 \\
\hline
\end{tabular}

İstanbul'da Bulgarların ikamet ettikleri semt ve mahallelere ve sayılarına bakarak yapabileceğimiz ilk tespit Bulgarların şehirde getto tarzı toplu bir yerleşime sahip olmadıkları, bilakis şehrin birçok yerinde dağınık bir şekilde yaşadıklarıdır. Bunun da temel sebebi İstanbul'da yaşayan Bulgarların şehrin hizmet sınıfını oluşturmuş olmasıdır. Bahçıvanlık, çiçekçilik, sütçülük, ekmekçilik gibi geçimlerini sağladıkları işlerle şehrin farklı mahallelerine dağılmışlardır. Örneğin Kasımpaşa'da yaşayanlar ağırlıklı olarak bahçıvanlık yapmaktadır. Buna karşılık Kuzguncuk, Bebek, Çengelköy, Yeniköy, Beylerbeyi gibi Boğaz mahallelerinde yaşayanlar genelde sütçü, fırıncı, muhallebici ve bahçıvandır. Eminönü çevresindeki hanlarda kalanlar ise daha çok abacılıkla uğraşan ve bekar olarak İstanbul' da bulunan kişilerdir. Fener bölgesinde oturanlar arasında tüccar, meyhaneci, tatlıcı, asker yanında yalnızca bir kişi sütçülük yapmaktadır. Burada biraz daha cemaat halinde yaşama özellikleri görülmektedir. Fakat asıl cemaat hayatının Şişli'de olduğu anlaşılmaktadır. Çünkü Bulgar okul ve hastanesinin Şişli'de bulunmaktaydı. Orada yaşayanların bir kısmı Bulgar hastanesinde çalışanlardır. Ayrıca Şişli'de tüccar, öğretmen, memur, işçi, duvar ustası, usta, kuyumcu, berber, ekmekçi gibi çok farklı meslekleri icra edenler de görülmektedir. Bu çeşitlilik bize Bulgarların Şişli gibi semtlerde daha fazla cemaat halinde yaşadıklarını göstermektedir. Mesleklerle ilgili detaylar ayrıca aşağıda incelenecektir.

37 Bugünkü Bankalar caddesi için bkz Murat Belge, İstanbul Gezi Rehberi, Tarih Vakfi Yurt Yay., İstanbul, 2007, s. 230 .

38 Bulgarca tercümesi "Bankanın karşısında". 
1923’te Lozan Antlaşmasından sonra tekrar bölgenin Türkiye'nin kontrolü altına girmesiyle Trakya' da yaşayan Bulgarların göç süreci hızlanmıştır. Buna sebep olarak, örneğin Kırklareli’nde bölge Türklerinin Bulgarlar üzerindeki baskıları ve hükümetin bunlara karşı yeterli önlemleri almaması gösterilmektedir ${ }^{39}$.

1923 ’te kararlaştırılan Türk-Yunan nüfus mübadelesinin İstanbul vilayetindeki Bulgarları da etkilediği anlaşılmaktadır. Edirne'de 36 Bulgar ve İstanbul vilayetinde yaklaşık 200 Bulgar nüfus defterlerine Rum olarak kayıtlı olduğundan bunların mübadele gereği Yunanistan'a gönderilmesi söz konusu olmuştur. Bulgar kilisesi, Bulgaristan hükümeti ve Ankara hükümetine başvurarak bunların Yunanistan'a gönderilmesini engellemeye çalışmış, bu amaçla Eksarh vekilliği bu kişilere “şehadetname” düzenlemiş ve Bulgaristan'a göç etmelerine izin verilmesini istemiştir ${ }^{40}$.

$\mathrm{Bu}$ süreçte Edirne gibi yerlerde de Bulgar cemaatinin ekonomisinin bozulduğu anlaşılmaktadır. Örneğin Edirne'de Bulgar cemaati, 1924 yılı ortalarında ekonomik durumlarının çok kötü olduğu gerekçesiyle Bulgaristan'dan yardım talep etmiştir. Yardım talep edenler arasında esnaflar da yer almıştır ${ }^{41}$.

1930'lara gelindiğinde İstanbul'daki Bulgarlar için şartlar daha da zorlaşmıştır. 1936'da yürürlüğe giren ve yabancı uyrukluların çalışmasını yasaklayan kanundan sonra İstanbul'da ikamet eden çok sayıda Bulgaristan vatandaşı Bulgar, mesleğini icra edemediğinden Bulgaristan'a göç etmek zorunda kalmıştır. Bunlar arasında terzi, abacı, bahçıvan, sütçü ve duvarcı olarak çalışanlar da vardır² ${ }^{42}$ Göç edenler arasında Türkiye Cumhuriyeti vatandaşı olup Bulgaristan vatandaşı Bulgarlarla evli olanlar da bulunmaktadır. Örneğin Zoya Todorova Çamova isimli kadın Türkiye vatandaşı olup kendisi gibi İstanbul'da yaşayan ama Bulgaristan vatandaşı olan kocası Save Dimitrov Vılçev'le birlikte Bulgaristan'a göç etmiştir ${ }^{43}$. Zaten çoğunluğu Bulgaristan vatandaşlığını almış olan İstanbul Bulgarları bu durumdan büyük ölçüde etkilenmiştir. İstanbul'daki Bulgarların karşılaştığı bu durumun, Bulgaristan'da 1934'te askeri darbeyle yönetime gelen hükümetin Bulgaristan Türklerine karşı uygulamaya koyduğu asimilasyon ve göç ettirme politikasından da etkilenmiş olduğu düşünülebilir.

\section{Bulgarların Meslekleri ve Ekonomik Durumu}

İstanbul'da bulunan Bulgaristan vatandaşları bahçıvanlık, sütçülük ve satıcılık, ekmekçilik, hizmetkârlık gibi işlerde çalışan kişilerdi. Bununla birlikte tüccarlık ve abacılık gibi işlerle uğraşanlar da vardı.

39 TsDA, F. $246 \mathrm{~K}$, op. 2 , a.e. $31,1.251,256-258,275-275$.

40 TsDA, F. 246K, op. 2, a.e. 31, 1. 169, 174-176, 179,182, 189. Örneğin Kurfallı ve Çatalca' da bazı Bulgarların Rumlarla birlikte mübadeleye dahil edilmesi, 1. 347-351.

41 TsDA, F. 246K, op. 2, a.e. 39, 1. 153-157.

42 TsDA, F. 246K, op. 2, a.e. 39, 1. 3-10, 16, 19, 31-40.

43 TsDA, F. $246 \mathrm{~K}$, op. 2, a.e. $31,1.40$. 
Cemaatin en genç hane reisi olarak Galata'da ve Bulgar tabiiyetinde olan 13 yaşındaki abacı Stamo Nikolov kaydedilmiştir ${ }^{44}$. En yaşlı hane reisi ise bahçıvan olarak Eyüp Sultan’da oturan ve Osmanlı tabiiyetinde bulunan Georgi İngilizov'dur ${ }^{45}$.

1917 tarihli defterde kayıtlı Bulgarların 506'sının mesleki dağılımı aşağıdaki gibidir ${ }^{46}$ :

\begin{tabular}{|c|c|c|c|c|c|}
\hline \multicolumn{6}{|c|}{$\begin{array}{c}\text { Tablo } 5 \\
\text { 1917'de İstanbul'da Yaşayan Bulgarların Meslekleri }\end{array}$} \\
\hline Meslek & Sayı & Yüzdesi (\%) & Meslek & Sayı & Yüzdesi (\%) \\
\hline Bahçıvan & 156 & $\% 30,8$ & Tatlicı & 2 & $\% 0,4$ \\
\hline Sütçü & 148 & $\% 29,2$ & Usta & 2 & $\% 0,4$ \\
\hline Abacı & 28 & $\% 5,5$ & Zerzevatçı & 2 & $\% 0,4$ \\
\hline Tüccar & 27 & $\% 5,3$ & Bağc1 & 1 & $\% 0,2$ \\
\hline Satıcı & 24 & $\% 4,9$ & Berber & 1 & $\% 0,2$ \\
\hline Ekmekçi & 23 & $\% 4,5$ & Demirci & 1 & $\% 0,2$ \\
\hline Hizmetkâr & 15 & $\% 2,9$ & Duvarc1 & 1 & $\% 0,2$ \\
\hline Asker & 10 & $\% 1,9$ & Dükkancı & 1 & $\% 0,2$ \\
\hline Çiçekçi & 10 & $\% 1,9$ & Eskici/tamirci & 1 & $\% 0,2$ \\
\hline Meyhaneci & 7 & $\% 1,3$ & Hamal & 1 & $\% 0,2$ \\
\hline İşçi & 6 & $\% 1,1$ & Helvacı & 1 & $\% 0,2$ \\
\hline Ayakkabıcı & 6 & $\% 0,9$ & Kasap & 1 & $\% 0,2$ \\
\hline Terzi & 5 & $\% 0,9$ & Kuyumcu & 1 & $\% 0,2$ \\
\hline İşkembeci & 4 & $\% 0,8$ & Muhallebici & 1 & $\% 0,2$ \\
\hline Firınc1 & 4 & $\% 0,8$ & Peynirci & 1 & $\% 0,2$ \\
\hline Aş̧̧1 & 3 & $\% 0,6$ & Rahip (papaz) & 1 & $\% 0,2$ \\
\hline Memur & 3 & $\% 0,6$ & İkonom ${ }^{47}$ & 1 & $\% 0,2$ \\
\hline Öğretmen & 3 & $\% 0,6$ & Kapıc1 & 1 & $\% 0,2$ \\
\hline Kahveci & 3 & $\% 0,6$ & Toplam & 506 & 100 \\
\hline
\end{tabular}

Listede yer alan toplam 518 hane reisinden 506'sının mesleği belirtilmiş, 12'sinin ise belirtilmemiştir. Mesleği belirtilmeyenler genellikle kadınlardır.

44 TsDA, F.246K, op.5, a.e. $275,1.11$

45 TsDA, F. 246K, op.5, a.e. $275,1.9$

46 TSDA, F 246 K, op. 5, a.e.275, 1. 2-22. Mesleklerin tespiti defterden tek tek sayılarak yapılmıştır.

47 Bulgarca sözlüğe göre idare memuru, kâhya, vekilharç gibi anlamlara gelmektedir. Bkz. Bılgarski Turski Reçnik, Der. N. Vançev vd, İzd. Na Bılgarskata Akademiya na Naukite, Sofya, 1961, s. 357. Bulgar cemaatinde ise kilisedeki ihtiyaçları temin eden ve mali hesapları tutan kişidir. 
Listede de görüldüğü gibi İstanbul'da Bulgarlar arasında en yaygın meslek bahçıvanlıktır. 1881-82 yıllarına ait çalışmada da yine bahçıvanlık en yaygın meslek olarak görülmektedir ${ }^{48}$. İncelediğimiz defterde bahçıvanlık yapan Bulgarların bazılarının bahçelerdeki küçük kulübelerde yaşadığını anlıyoruz. Bazı anılarda İstanbul'da meyve ile sebze yetiştiriciliği yapan Bulgarların bulunduğu, bahçe kiralayarak ailelerine baktıkları ve para kazandıkları anlatılmaktadır. Bahçıvanlık mesleği 19. yüzyılın ortalarında da İstanbul'a yerleşen Bulgarların ana mesleklerinden biriydi. Meşhur Bulgar diplomat ve yazar Simeon Radev'in dedesi de Resne'nin Sıpot köyünden gelerek İstanbul'da bahçıvanlık yapmıştır. Simeon Radev İstanbul'da Galatasaray Lisesi'nde okumuştur ${ }^{49}$.

Bahçıvanlık kadar yaygın bir diğer meslek sütçülüktür. Bahçıvanlık ile sütçülük Bulgarların yaklaşık üçte ikisinin geçimini sağladığı başlıca meslekler olarak dikkat çekmektedir.

Abacılık ise Bulgarların Osmanlı yetkilileriyle ilk önemli bağını kuran meslektir. Bu meslek sayesinde birçok abacı tüccarı ailesiyle birlikte burada yaşardı. Bu kesim 19. yüzyılın ortalarında Bulgar kilise mücadelesini başlatan kesimdir. Bu mesleklerin dışında dikkat çeken başka bir husus, 10 tane asker kaydedilmesidir. Bunların çoğu Bulgar tabiiyetinde olmasına rağmen Osmanlı tabiiyetinde olanlar da vardır. Ayrıca memur olarak kaydedilenlerin ikisinin Bulgar tabiiyetindeyken birinin Osmanlı tabiiyetinde olduğu görülmektedir.

1920 başlarında İstanbul'daki Bulgarların sütçülükteki konumunun zayıfladığ1 anlaşılmaktadır. İstanbul'daki Bulgar cemaatinin lideri Eksarh vekili 25 Ağustos 1922 tarihli raporunda İstanbul' da son zamanlarda modern teknolojiyle süt ve süt ürünleri üretimi yapan "yabancı" sütçülerin arttığını ve Bulgarların ise eski usul üretim yaptıklarını, bu nedenle işlerini kaybetmeye başladıklarını belirtmiştir. Bulgaristan'dan İstanbul'a bir uzman gönderilmesini ve modern üretim hakkında kurs açılmasını talep etmiştir ${ }^{50} .1923$ Şubat ayında Bulgar hükümeti Hr. Dimitrov isimli “öğretmen-sütçü”yü iki seferlik 1.5'er aylık (toplam üç ay) kurslar vermek üzere İstanbul'a göndermeye karar vermiştir ${ }^{51}$. İstanbul'un İngiliz işgali altında bulunduğu bu dönemde yabancı sütçülerin, Bulgarların sütçülük pazarına ortak olduğu anlaşılmaktadır. Fakat bu "yabancı" sütçüler hakkında daha fazla bilgi verilmemektedir.

Mesleklerden biri olan işkembecilik hakkında ailesi Makedonya Zagoriçeni/KesriyeKostur kökenli olan Georgi Pandev Kostandov'un (d. 1944) eserinde detaylı bilgiler yer almaktadır. Eserini 2011'de yayınlayan Kostandov'un büyük dedesi ve dedesi İstanbul'da Unkapanı'nda ve daha sonra Mahmutpaşa'da işkembecilik yapmaktaydı. Bu mesleğin incelikleri ve bu meslek erbabının hayatıyla ilgili önemli bilgiler vermektedir ${ }^{52}$. 1917 'de dört

48 Sibev, a.g.e., s. 75.

49 Simeon Radev, Ranni Spomeni, İzd. B1lgarski Pisatel, Sofya 1969, s. 9-10.

50 TsDA, F. 246 K, op. 2, a.e. $31,1.37$.

51 Aynı yer, 1. 37.

52 Kostandov, İstanbullu Bulgarlar, s. 265-279. 
Bulgar işkembecinin bulunduğu İstanbul'da, 1950'lerde de yine dört Bulgar işkembecinin mevcut olduğunu belirtmektedir ${ }^{53}$.

\section{Bulgar Cemaatinin Dini, Sosyal ve Kültürel Hayatı}

İstanbul Bulgar cemaatinin en önemli müessesesi, 1870' de kurulmuş olan Eksarhhanedir. $\mathrm{Bu}$ kurumun başında Eksarh Yosif bulunuyordu. Yalnızca Osmanlı Devleti içindeki Bulgarların değil tüm Bulgarların dini lideri konumundaydı. 1912/1913 Balkan savaşlarına kadarki süreçte Makedonya ve Edirne bölgesinde çok sayıda okul ve kilise Eksarhhane'nin kontrolü altındaydı. Eksarhhane'nin en yakınında ise İstanbul'daki Bulgar cemaati bulunuyordu. Eksarhlık yalnızca din işleriyle değil, İstanbul Bulgarlarının II. Meşrutiyet dönemi siyasal hayatına katılımında da liderlik yapmıştır. Aynı zamanda okulların açılması ve yönetilmesiyle de doğrudan ilgileniyordu. Ayrıca Bulgarların kültür hayatında da önemli bir yere sahipti. Bu kültürel canlılık Balkan savaşlarına kadar devam etti. Örneğin 1912 yılında, Balkan savaşlarının hemen öncesinde, Bulgar Eksarhlığı "Vesti” ve "Glas" isimli gazeteleri çıkarıyordu. Cemaatin bu gazetelere abone olması zorunlu tutulmuştu. Buna göre şehir rahipleri 20 kuruş, köy rahipleri 15 kuruş, yıllık geliri 1-20 Türk Lirası olanlar 15 kuruş, 21-36 lira arası 30 kuruş, 37-71 lira arası kazananlar 40 kuruş, 72-119 arası 60 kuruş, 120 liradan çok kazananlar 80 kuruş gazete ve vereceği ekler için abonelik bedeli ödeyecekti5 ${ }^{54}$.

19. yüzyılın ortalarından itibaren devam eden Rum-Bulgar rekabeti ve husumeti II. Meşrutiyet'in ilk yıllarında da devam etmiştir. Fakat Balkan savaşlarının hemen öncesinde Osmanlı'ya karşı Bulgaristan, Sırbistan ve Yunanistan arasında ittifak anlaşmalarının imzalanmaya başlaması Bulgar cemaatinin Rum cemaatiyle ilişkisini de etkiledi. Balkan savaşının patlak vermesinden yaklaşık iki buçuk ay önce, 30 Temmuz 1912'de Bulgar Eksarhı Yosif metropolit ve piskoposlara yazdığı talimatta, Osmanlı İmparatorluğu'nda yaşayan Ortodoks Hıristiyanların gerçek menfaatlerinin anlaşılması sayesinde Bulgar-Rum uzlaşması sağlandığını belirtmektedir. O zamana kadar Bulgarlar ile Rumlar arasındaki kötü ilişkiler ve husumetin hep birbirlerine zarar verdiğini ve buna her zaman üzüldüğünü, bunların sona ermesi gerektiğini vurgulamaktadır. Metropolitlerden ve diğer cemaat liderlerinden bu ittifaka destek olmalarını talep etmektedir ${ }^{55}$.

1908 ile 1912 arasında İttihat ve Terakki Cemiyeti’nin kontrolündeki Osmanlı hükümeti ile Bulgar Eksarhlığı arasında yaşanan gerilim (özellikle okulların denetimi konusunda yaşanan yetki mücadelesi) Eksarhhane'nin bu tavrında şüphesiz etkili olmuştur ${ }^{56}$.

53 Kostandov, a.g.e., s. 278.

54 Eksarh Yosif'ten metropolitlere, 14 Mart 1912, TSDA, F. 246 K, op.3, a.e. 124, 1. 26-28.

55 Eksarh Yosif'ten metropolitlere, 30 Temmuz 1912, TSDA, F. 246 K, op.3, a.e. 124, 1. 50.

56 Konunun detayları için bkz. Mehmet Hacısalihoğlu, “İttihadçıların 'Kültür Kavgası': Bulgar Eksarhlığı ve Okul Meselesi”, Sultan Mehmed Reşad ve Dönemi, c. I, ed. Yasin Yıldız vd., Milli Saraylar, İstanbul 2018, s. 184-203. 
Balkan savaşları sonrası Bulgar Eksarhı I. Yosif, Sofya'ya taşındı ve İstanbul'daki faaliyetler Eksarhlık Meclisi ve vekili tarafından takip edildi. Bu dönemde Metropolit Veles bu vazifeyi yürütmüştür. Bulgarların durumuna dair en detaylı bilgileri Sofya' daki Eksarhlığın Meclisine gönderilmek üzere hazırlanmış bir rapordan öğreniyoruz. Buna göre Metropolit, bu göreve gelmeden önce Eksarh Yosif tarafından uyarılmıştır. Sadece "mümkün olduğunca mevcut durumun korunması için" çaba sarf etmesi istenmiştir. Metropolit ise bu görevi elinden geldiğince yerine getirmeye çalıştığını beyan etmiştir. 26 Ağustos 1915 tarihli bir belge, Bulgar kilisesi "Sveti Stefan"la ilgili bilgiler içermektedir. Bu kilisenin masraflarının karşılanması için ve gelir oluşturmak için toplam 9 kişilik bir idare heyetinin kurulduğu ve her ay toplanıldığı belirtilmiştir. Kilisenin sadece yortu günlerinde değil diğer günlerde de çok sık ziyaret edildiğinden, idare heyeti olarak Bulgar dindaşlarından serbest bir vergi toplanmaya karar verilmiştir. Toplanan paradan 110 Türk lirasının borçların kapanmasına ve kalan paranın bekçi maaşı, papaz ve kilisenin diğer giderlerine harcandığı belirtilmiştir. Eksahlığın yanındaki Papazevinin ise açık tutulduğu, Pera ve Şişli'de yaşayan 40 civarında Bulgar ailesi tarafında düzenli olarak ziyaret edildiği ifade edilmiştir ${ }^{57}$.

Bulgar kilisesinin kendisine ait bazı taşınmaz mülkleriyle ilgili de bilgiler vardır. Balkan savaşları sonrası Fener'deki Bulgar kilisesi, Kırklareli ve Edirne'deki iki kilise, Şişli'deki Eksarhlık binası, Ortaköy'deki eski Eksarhlık binası, onun yanındaki ev, Şişli'deki eski seminer binası, Pera'daki okul binası, Langa'daki mahalle okul mektebi binası, Feriköy'de Bulgar mezarlığı, Edirne'deki Dr. Beronov Lise binası ve Edirne'deki Metropolit binası Bulgarlara ait taşınmazlardır ${ }^{58}$.

İstanbul'da Bulgarların yoğun olarak yaşadığg semtlerde kiliseye bağlı okullar mevcuttu. Balkan savaşından sonra İstanbul'da 3 sınıflık Pera ve Langa ile Fener'de ilk ve ortaöğretim okulları mevcuttu. Daha sonra İstanbul'un köyleri olan Terkos, İmrahor ve Tayakadın' da ${ }^{59}$ birer okul daha açılmıştır ${ }^{60}$. İstanbul'daki Bulgar okullarında 1913-14 yılında toplam 228 öğrenci vardı, 1914-1915'te bu sayı 295'e yükselmiştir. Aynı tarihlerde Langa okulunun binası satın alınmıştır. Bu bina için yerli halktan 250 lira toplanmış ve 800 lira da Bulgaristan Hükümeti tarafından gönderilmiştir. 1914-15 öğretim yılında İstanbul'daki Pera Bulgar okulunda 7 tane öğretmen görev yapmıştır. Tr. Zafirov okulun müdürüdür ve üç sınıfta haftalık toplam 13 saat Bulgarca derslerine girmektedir. Fener Bulgar Okulunda tek öğretmen, Langa'daki okulda ise 3 öğretmen görev yapmıştır. Bu okullarda 6 saat Türkçe dersi de yapıldığg belirtilmektedir ${ }^{61}$. Birinci Dünya Savaşı döneminde Osmanlı Devleti’nin

57 Fener'deki kilise ayinlerinin iki papaz tarafından yapıldı̆̆ını, papazevi de yine faaliyette olduğu belirtilmiştir. TsDA, F. 246 K, op. 2, a.e.15, 1. 2.

58 TsDA, F. $246 \mathrm{~K}$, op. 2, a.e. $15,1.3$.

59 Padişahların kızlarını veya şehzadelerini emziren kadınlara dâye, tâye veya sütnine denirdi. Bkz. M. Çă̆atay Uluçay, Harem, II, Ankara 2001, s. 138-140. Günümüzde Tayakadın, Arnavutköy’e bağlı bir köydür.

60 TsDA, F. 246 K, op. 2, a.e.15, 1. 2.

61 TsDA, F. 246 K, op.3, a.e. 241, 1. 539- 540. 
yabancı okullara yönelik bazı imtiyazları kaldırmış olmasına rağmen, İstanbul'daki Bulgar okullarına yönelik herhangi bir kısıtlama yapılmadığı anlaşılmaktadır ${ }^{62}$. Bunda şüphesiz savaşta Bulgaristan ile Osmanlı Devleti'nin müttefik olması da etkili olmuştur.

İstanbul'da bulunan Bulgar okullarındaki bütün öğretmenlerin isimleri ve onlarla ilgili kısa bilgilerin yer aldığı raporlar tutulmuştur. Bulgar Ruhban Okuluna (Seminaria) ait bir de kütüphane mevcuttur. Fakat bu dini okul Balkan savaşları döneminde kapatılmıştır ve Eksarh Yosif Bulgaristan’a gitmiştir. Bu okula devam eden birçok öğrenci daha sonra dilekçe vererek okulun tekrar açılmasını talep etmişlerdir. Bu dilekçelerde bazı öğrenciler kendi ailelerinin maddi durumuna dair bilgiler de vermiştir. Belgeler arasında mezuniyet belgeleri ve vaftiz belgeleri de bulunmaktadır.

Bulgar cemaatine ait Şişli'de Evlogi Georgiev Hastanesi adıyla 1902'de kurulmuş bir de hastane mevcuttu ${ }^{63}$. Bu hastane Bulgar cemaatinin sağlık koşulları açısından da önemliydi. Belli dönemlerde hastanede ihtiyacı olanlara ücretsiz olarak muayene olma imkânı da sağlanabiliyordu. 1919 yılında Rusya'dan İstanbul'a sığınan Beyaz Ruslar için de hastanede ücretsiz muayene ve tedavi olma imkânı gündeme gelmiştir. Sofya'da bulunan “Türkiye'deki Ruslara Yardım Komitesi”, Balkan savaşları döneminde Rusların hastanenin Osmanlı hükümeti tarafından kapatılmasını önlemek için yardım ettiğini hatırlatarak şimdi de yardıma muhtaç olan Ruslara hastanenin ücretsiz hizmet vermesini istemiştir ${ }^{64}$.

\section{Sonuç}

İstanbul'un fethiyle Bulgarlar bu şehre iskân edilmeye başlamıştır. Fakat Bulgar nüfusunun en yoğun olduğu dönem 1826'da Yeniçeri Ocağı'nın kaldırılması ve yeni ordunun kurulmasıyla başlar. Ordunun ihtiyacı olan elbiselerin dikimi için birçok Bulgar bu dönemde İstanbul'a gelmiştir. Bu tarihten 1912-1913 Balkan Savaşlarına kadar İstanbul'daki Bulgar cemaatinin sayı ve önem bakımından devam eden bir gelişme gösterdiği görülmektedir. Fakat Balkan savaşlarıyla birlikte Osmanlı Devleti'nin yaşadığı büyük kayıplar ve Müslümanların maruz kaldığı katliam ve tehcirler İstanbul'daki Bulgar cemaatini de olumsuz etkilemiştir. Bu makalede esas olarak Balkan savaşları sonrasında İstanbul'da kalan Bulgarların durumu ortaya konmaya çalışılmıştır.

İlk olarak 1913'e kadar genişleyen cemaatin bu yıldan itibaren hızla küçüldüğü, etkisini ve önemini kaybetmeye başladığı görülmektedir. Dünya Savaşı döneminde İstanbul'daki Bulgar cemaatinin sayısı 2.000'den biraz az bir yekûn oluşturmuştur. Büyük çoğunluğu

62 TsDA, F. 246 K, op. 2, a.e. 15, 1. 2.

63 Hastanenin kuruluşuna öncülük eden Evlogi Georgiev hakkında bkz. Daritelite: Evlogiy i Hristo Georgievi, haz. Elka Drosneva, Izdadelstvo “Lik”, Sofya 1988.

64 Eski İstanbul Rus konsolosu ve "Komitet Pomoşti Russkim v Turtse” başkanı Çarikov'un hastane başhekimine mektubu, TsDIA, F. 1458K, op. 1, a.e. 166, 1. 4. 
Batı Makedonya bölgesinden gelen Bulgarların İstanbul'da yaşadığg belli başlı semtler Şişli, Kasımpaşa, Galata, Fener gibi merkezler olmuştur. Meslek olarak Bulgarların yaklaşık üçte ikisi bahçıvanlık ve sütçülükle geçimlerini sağlamışlardır. Satıcılık, ekmekçilik ve hizmetkârlık meslekleri ise Bulgarlar arasında \%12 civarındadır. Bu şekilde Bulgar cemaatinin çoğunlukla küçük esnaf sınıfını oluşturduğu anlaşılmaktadır. Bunun yanında tüccarlık ve abacılık da Bulgarlar arasında önemli sayılabilecek meslekler olarak dikkat çekmektedir.

Balkan Savaşlarından sonra nüfus ve ekonomik hayatta olduğu gibi okul ve eğitim hayatında da bir daralma olduğu görülmektedir. Bununla birlikte Bulgar Eksarhlığı'nın kontrolündeki okullar Dünya Savaşı döneminde yabancı misyoner okulları gibi bir muameleye maruz kalmamışlardır. Bulgaristan'la Osmanlı Devleti'nin ittifak halinde olmasının da bunda önemli bir etkisi olduğu söylenebilir.

Özetle Sultan Mehmed Reşad dönemi (1909-1918) Bulgar cemaatinin gücünün zirvesine ulaşıp hızla küçülmeye başladığı bir dönem olmuştur. Daha sonraki yıllarda ise cemaatin durumu daha da zayıflamış ve büyük çoğunluğu Bulgaristan’a göç etmiştir.

Hakem Değerlendirmesi: Dış bağımsız.

Çıkar Çatışması: Yazar çıkar çatışması bildirmemiştir.

Finansal Destek: Yazar bu çalışma için finansal destek almadığını beyan etmiştir.

Peer-review: Externally peer-reviewed.

Conflict of Interest: The author has no conflict of interest to declare.

Grant Support: The author declared that this study has received no financial support.

\section{Kaynakça/References}

\section{Arşiv Kaynakları}

\section{Başkanlık Osmanlı Arşivi (BOA)}

Sadaret Eyâlât-1 Mümtaze-Bulgaristan Evrakı (A.MTZ (04))

Hariciye Nezareti Paris Sefareti (HR.SFR (04)).

Yıldız Esas Evrakı Defterleri (YEE).

\section{Bulgaristan Merkez Arşivi (Tsentralen Dırjaven Arhiv) TsDIA}

TsDIA, F. 246 K, op. 2, a.e. 15.

TsDIA, F. 246K, op. 2, a.e. 31.

TsDIA, F. 246K, op. 2, a.e. 39.

TSDA, F. 246 K, op.3, a.e. 124.

TsDIA, F. 246 K, op.3, a.e. 241.

TsDIA, F. 246 K, op. 5, a.e. 275.

TsDIA, F. $1458 \mathrm{~K}$, op. 1, a.e. 166. 


\section{Araştırma Eserler}

Adanır, Fikret, Makedonya Sorunu, Oluşumu ve 1908'e Kadar Gelişimi, çev. İ. Catay, Tarih Vakfı Yurt Yay., İstanbul 2001.

Ahbab, Yakup, “Amerikan ve İngiliz Basınında İlinden İsyanı (1903)”, Karadeniz Araştırmaları Enstitüsü Dergisi, I/1 (2015), s. 119-151.

Aydın, Mahir, “Arşiv Belgeleriyle Makedonya'da Bulgar Çete Faaliyetleri”, Osmanlı Araştırmaları, sayı IX (1989), s. 209- 234. , Şarki Rumeli Vilayeti, TTK Yay., Ankara 1992.

Belge, Murat, Istanbul Gezi Rehberi, Tarih Vakfı Yurt Yay., İstanbul, 2007

Beydilli, Kemal, “II. Abdülhamid Devrinde Makedonya Meselesine Dair”, Osmanlı Araştırmaları, sayı IX'dan ayrı basim (1989), s. 77-98.

Bılgarski Turski Reçnik, Der. N. Vançev vd, İzd. na Bılgarskata Akademiya na Naukite, Sofya, 1961.

Daritelite, Evlogiy i Hristo Georgievi, haz. Elka Drosneva, Izdadelstvo “Lik”, Sofya 1988.

Ersoy Hacısalihoğlu, Neriman, "Textile Trade in Bulgaria in the Mid-Nineteenth Century and the Gümüşgerdan Family", Living in the Ottoman Ecumenical Community: Essays in Honour of Suraiya Faroqhi, ed. Vera Costantini, Markus Köller, Brill, Leiden 2008, s. 181-199.

“19. Yüzyıl İstanbul'unda Bulgar Tüccarları ve Bulgar Cemaati”, Ístanbul: Imparatorluk Başkentinden Megakente, ed. Yavuz Köse, çev.A. Dağl1, Kitap Yay., İstanbul 2011, s. 176-199.

"Bulgar Eksarhı Yosif'in Yazışmalarında Makedonya'daki Bulgar Okulları", Osmanlıdan Cumhuriyete Sosyo-Kültürel Siyasi Yansımalar, (Prof. Dr. Ali İhsan Gencer Anısına), ed. G. Sarıyıldız, F. Ürekli, R. Karacakaya, N. E. Hacısalihoğlu, Derin Yay., İstanbul 2015, s. 137-156

, XIX. Yüzyılda Filibe Şehri (1839-1876), İstanbul Üniversitesi Sosyal Bilimler Enstitüsü, Yayınlanmamış Doktora Tezi, İstanbul 2004.

Hacısalihoğlu, Mehmet, “İttihadçıların 'Kültür Kavgası’: Bulgar Eksarhlı̆̆ı ve Okul Meselesi”, Sultan Mehmed Reşad ve Dönemi, c. I, ed. Yasin Yıldız vd., Milli Saraylar, İstanbul 2018, s. 184-203.

, "The Rise of Sliven (İslimye) from a Balkan Village to a Province Center in the Ottoman Empire", Turkey and Bulgaria. A Contribution to Balkan Heritage, International Balkan Annual Conference IBAC Book Series 5, ed. Özgür Kolçak, İstanbul Üniversitesi Yay., İstanbul 2017, s. 75-100.

, Doğu Rumeli'de Kayıp Köyler: Isslimye Sancă̆ı'nda 1878'den Günümüze Göçler, İsim Değişiklikleri ve Harabeler, Bağlam Yay., İstanbul 2008, s. 74-77. 2008.

, Jön Türkler ve Makedonya Sorunu (1890-1918), çev. İ. Catay, Tarih Vakfı Yurt Yay., İstanbul

Karpat, Kemal H., Ottoman Population, 1830-1914: Demographic and Social Characteristics, The Univ. of Wisconsin Press, Madison 1985.

Kayapınar, Ayşe, “XV. ve XVI. Yüzyılda Bulgaristan Coğrafyasından İstanbul'a Yapılan Sürgünler ve İskân”, Osmanlı İstanbulu V: V. Uluslararası Osmanlı İstanbulu Sempozyumu Bildirileri, 19-21 Mayls 2017, ed. Feridun M. Emecen, Ali Akyıldız, Emrah Safa Gürkan, İstanbul 29 Mayıs Üniversitesi Yay., İstanbul 2018, s. 268-269.

Kostandov, Georgi P., İstanbullu Bulgarlar ve Eski İstanbul: Geçmişten Günümüze Osmanlı Bakiyesi Bulgarlar Üzerine Bir Araştırma, Kreatif, İstanbul 2011. 
Macar, Elçin, İstanbul'un Yok Olmuş İki Cemaati. Doğu Ritli Katolik Rumlar ve Bulgarlar, İletişim Yay., İstanbul 2002.

Mevsim, Hüseyin, Bulgar Gözüyle İstanbul: Karanov, Macarov, Naçov, TTK Yay., Ankara 2011.

Naçov, Naço, "Tsarigrad kato Kulturen Tsentır na Bılgarite do 1877”, Sbornik na BAN, Klon İstorikoFilosofski i Filosofsko-Obştestven, (19/25), 1925, s. 1-206.

Radev, Simeon, Ranni Spomeni, İzd. B1lgarski Pisatel, Sofya 1969.

Sabev, Orlin, "Bulgaristan'da Muhafaza Edilen 1299/1881-82 Tarihli Bir Nüfus Defterine Göre Osmanlı İstanbulu'nun Bahçe ve Dükkanlarında Çalışan Bulgarlar”, Osmanlı İstanbulu V: V. Uluslararası Osmanlı İstanbulu Sempozyumu Bildirileri, 19-21 Mayls 2017, ed. F. M. Emecen, A. Aky1ldı, E. S. Gürkan, İstanbul 29 Mayıs Üniversitesi Yay., İstanbul 2018, s. 605-621.

Sıbev, Orlin, Prosveteni na Iztok s Lıçite na Zapada: Bılgarskata Uçeniçeska Koloniya v Tsarigrad (XIX-XX Vek), Izd. “Avangard Prima”, Sofya 2019.

Stoyanova, Vanya, "Kım Vıprosa na Çislenostta na Tsarigradskata Bılgarska Koloniya (1913-1945)", Sine ira et studio, Izsledvaniya v Pamet na Prof. Zina Markova, ed. Konstantin Kosev, Aİ. "Prof. Marin Drinov", Sofya 2010, s. 415-424.

Şentürk, M. Hüdai, Osmanlı Devleti'nde Bulgar Meselesi (1850-1875), TTK Yay., İstanbul 1992.

Tekeli, İlhan, "Makedonya İç Devrimci Örgütü ve 1903 İlinden Ayaklanması”, Cumhuriyetin Harcl/Köktenci Modernitenin Doğuşu, haz. İlhan Tekeli-Selim İlkin, 3. Bask1, Bilgi Üniversitesi Yay., İstanbul 2010, s. 67-77.

Tokay, Gül, Makedonya Sorunu. Jön Türk İhtilalinin Kökenleri (1903-1908), Alfa Yay., İstanbul 1996.

Uluçay, M. Çağatay, Harem, II, TTK Yay., Ankara 2001. 


\section{EK}

1917'de İstanbul'da yaşayan Bulgarların kaydedildiği defterin ilk sayfası (Kaynak:

F. 246K, op. 5, a.e. 275.)

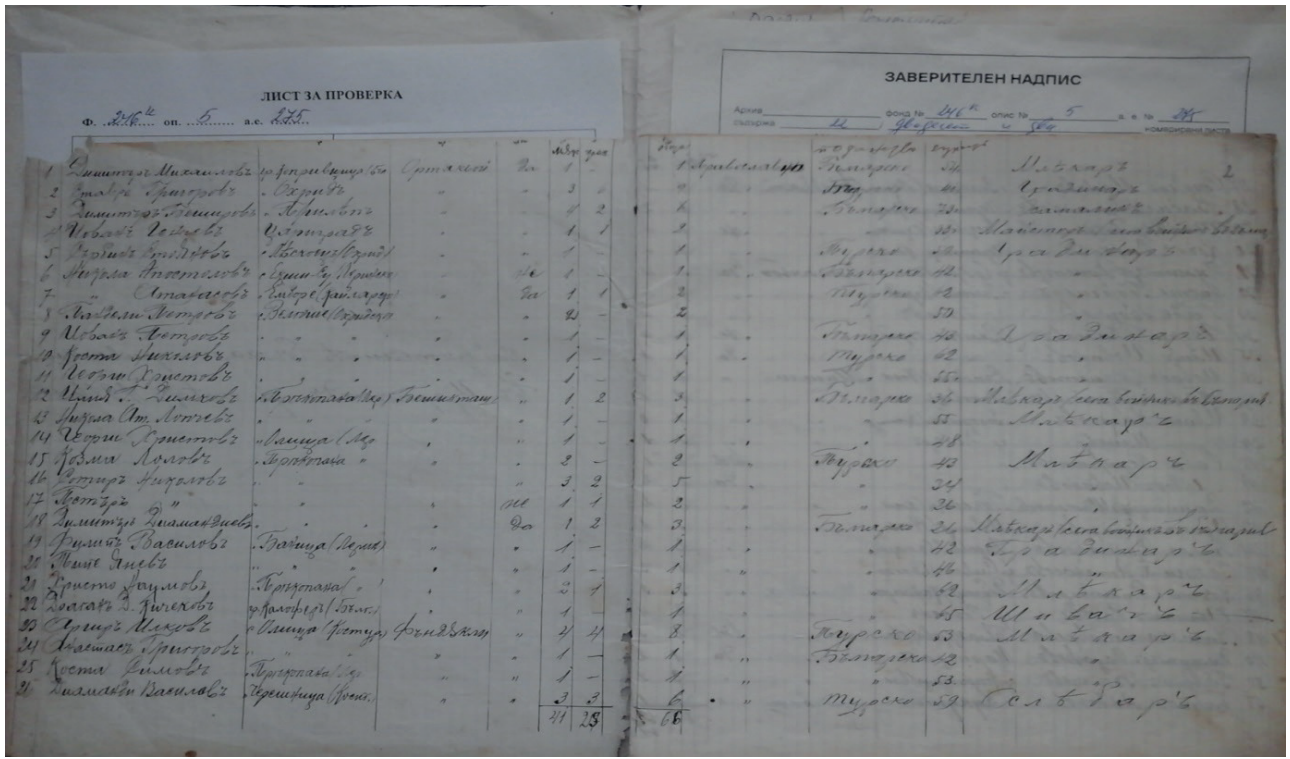

